日臨外会誌 $64(4), 785-790,2003$

原著

胃癌・大腸癌術後肺動脈塞栓症の検討と弾性ストッキングによる予防法

松下記念病院外科, 同 循環器科*

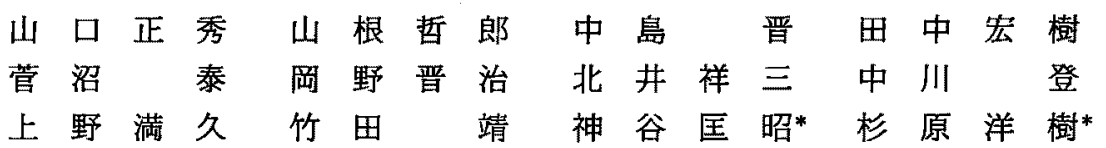

近年, 増加傾向にある消化器癌術後の肺動脈塞栓症について, 当院における本症の検 討と予防法と効果を検討した。 1996年 1 月より2001年 1 月の 5 年間で胃, 大腸癌の手術 後の肺動脈塞栓症を 8 例経験した。症例の年龄は48歳から84歳までで, 男性 2 例と女性 6 例であった. $20 \%$ 以上の肥満を認めたのは 3 例のみであった. 術式は 3 例は直腸切断 術, 4 例恃胃覀全摘術であった. 治療は 7 例で抗凝固療法を行い, 3 例に下大静脈フ ルターの留置が必要であった. 1 例のみ治療経過中確定診断ができず, 死亡例となった。 消化器癌術後肺動脈塞栓症の原因は，種々考えられるため, 症例ごとに術前に完全に肺 動脈塞栓症が発症するか否かを判断するのは困難でり, 肺動脈塞栓症の予防が最も重 要で効果的治療と思われる.ストッキング使用前後の時期ごとの患者背景には統計上有 意差はなく, 明らかに肺動脈塞拴症の発症頻度が低下しており, 弾性ストッキングは, その予防に有効と考えられた。

索引用語 : 肺動脈塞栓症予防, 胃癌・大腸癌術後, 弾性ストッキング

\section{緒 言}

欧米では, 手術後の肺動脈塞栓症の発生はその頻度 が高く, 常に, 注意を要する疾患である. 以前法本邦 では, その発生頻度は低く, 本症への対策は活とんど されていなかった, しかし, 近年, 食生活の欧米化, 生活罢境の変化により, その発度頻度は高くなりつつ あり, 疾患そのものが, 新聞, 雑誌などで一般に取り 上げられる機会も増加してきた，今回，胃癌，大腸癌 における消化器癌術後に肺動脈塞栓症を 8 症例経験 し，その症例の検討ならびに予防法としての弾性スト ッキングの有用性について検討した。

\section{対象と方法}

1996年 1 月より 2001 年 1 月までの 5 年間に, 全身麻 醉下大腸癌, 胃癌術後症例593例を対象とし, その内肺 動脈塞栓症と診断した症例は 8 症例で1.3\%であった. 肺動脈塞栓症の診断は，肺動脈塞栓症状を臨床上，ま たはモニターなどの検查值上異常を認めた症例に対し

2001 年12月13日受付 2003 年 1 月 6 日採用

〈所属施設住所〉

\%570-8540 守口市外島町 5-55
て, 病理解剖で診断した 1 例を除き, 肺血流シンチや 肺動脈造影の欠損像で行った。さらに，その主な原因 である下肢静脈血栓症の診断のため骨盤下肢 MRI 造 影や下肢静脈造影も行った。 8 症例について男女比, 年齢, 肥満度, 原疾患, 手術, 発症時期, 臨床所見, 画像診断, 検査所見, 治療内容, について検討した. また，その予防対策についてはその予防法によって期 間を 3 期に分類した. 1996年 1 月から1999年1月の特 に予防策を行っていない期間をI期とし，1999年 2 月 から11月の手術時間中弾性包帯を使用した期間をII期 とし，さらに1999年12月から2001年 1月の術前から術 中ならびに術後歩行が十分可能になるまで, 下肢を末 梢から段階的に圧が低くなる弾性ストッキング (graded compression stocking) を使用した期間をIII期と し, それぞれの期間にちける肺動脈塞栓症の臨床的発 生頻度について検討した。 また, その際に 3 期の各時 期の症例背景を比較して, 男女比, 年数, 大腸㾌の比

(胃癌と大腸癌の症例総数における大腸癌の割合), 直 腸癌手術の比(結腸癌と直腸癌の手術総数における直 腸癌の割合), 肥満度, 手術時間, 麻酔時間, 輸血の有 無に加えて, 全身麻醉下術前の肺動脈塞栓症の危険因 
表 1 全身麻酥術後肺動脈塞栓症危険因子評洒

\begin{tabular}{|c|c|}
\hline \multicolumn{2}{|l|}{ 危険因子 (各因子 1 点) } \\
\hline 標準体重上り20\%以上の肥満 & 敗血症 \\
\hline 41 歳 -60 歳 & 心血管疾患 \\
\hline 61歳 -70 歳 (2因子) & 外傷 \\
\hline 70歳以上 (3因子) & 骨折の既往 \\
\hline 下肢静脈血栓症の既往 (3因子) & 下肢静脈睑 \\
\hline 手術時間2時間以上 & 㮸血栓症の既往 \\
\hline 悪性疾患 & エストロゲン製㓮の投与 \\
\hline 大手街の既往 & 炎症性腸矤患 \\
\hline $\begin{array}{l}\text { 下肢浮腫, 謴瘍, うつ滞 } \\
\text { 血拴性血液采因 }\end{array}$ & 姡娠 \\
\hline \multicolumn{2}{|c|}{ 輸血, 䅯尿病, 腸閉塞など循環系に影響する疾患 } \\
\hline \multicolumn{2}{|c|}{ 你険因子合棓 (各应例ごと) } \\
\hline 低リスク 1点 中リスク 2-4点 & スク 5点以上 \\
\hline
\end{tabular}

表 2 I 期 II 期 III 期各時期の患者背景の比較 各時期で統計上有意差認めず（有意水準 $5 \%$ ）

\begin{tabular}{|c|c|c|c|c|c|c|c|c|c|c|}
\hline & $\begin{array}{c}\text { 男性比 } \\
\%\end{array}$ & $\begin{array}{c}\text { 女性比 } \\
\%\end{array}$ & $\begin{array}{c}\text { 年蒢 } \\
\text { 歳 }\end{array}$ & $\begin{array}{c}\text { 大腸瘦 } \\
\%\end{array}$ & $\begin{array}{c}\text { 直腸癌 } \\
\%\end{array}$ & $\begin{array}{c}\text { 肥満度 } \\
\%\end{array}$ & $\begin{array}{c}\text { 手街時間 } \\
\text { 分 }\end{array}$ & $\begin{array}{c}\text { 柇醉時間 } \\
\text { 分 }\end{array}$ & $\begin{array}{c}\text { 輸血の有無 } \\
\%\end{array}$ & $\begin{array}{c}\text { 血栓危険因子 } \\
\text { 点 }\end{array}$ \\
\hline I 期 & 65 & 35 & $\begin{array}{c}60.9 \\
\pm 11.29\end{array}$ & 49.6 & 30.2 & $\begin{array}{c}0.17 \\
\pm 14.35\end{array}$ & $\begin{array}{c}267.2 \\
\pm 117.66\end{array}$ & $\begin{array}{l}336.63 \\
\pm 120.1\end{array}$ & 7.9 & $\begin{array}{c}4.1 \\
\pm 1.23\end{array}$ \\
\hline II期 & 58.3 & 41.7 & $\begin{array}{c}62.92 \\
\pm 11.67\end{array}$ & 47.6 & 35 & $\begin{array}{c}2.7 \\
\pm 14.39\end{array}$ & $\begin{array}{c}259.01 \\
\pm 102.88\end{array}$ & $\begin{array}{c}328.45 \\
\pm 105.34\end{array}$ & 6 & $\begin{array}{c}4.7 \\
\pm 1.36\end{array}$ \\
\hline III期 & 65 & 35 & $\begin{array}{c}63.53 \\
\pm 11.55\end{array}$ & 48.3 & 25.9 & $\begin{array}{c}1.55 \\
+13.28\end{array}$ & $\begin{array}{c}244.62 \\
\pm 104.19\end{array}$ & $\begin{array}{c}314.49 \\
+106.51\end{array}$ & 7.6 & $\begin{array}{l}4.82 \\
\pm 1.4\end{array}$ \\
\hline & & & $\begin{array}{c}\text { mean } \\
\pm \mathrm{SD}\end{array}$ & & & $\begin{array}{l}\text { mean } \\
\pm \mathrm{SD}\end{array}$ & $\begin{array}{c}\text { mean } \\
\pm \mathrm{SD}\end{array}$ & $\begin{array}{c}\text { mean } \\
\pm \mathrm{SD}\end{array}$ & & $\begin{array}{c}\text { mean } \\
\pm \mathrm{SD}\end{array}$ \\
\hline
\end{tabular}

子の評価を参考にしり，術中の危險因子を加え症例ご とに点数化して合計し術後の肺動脈塞栓症危険因子を 点数で評価した（表 $1 ， 2$ ）。また，統計学的評価は， スチューデントの $\mathrm{t}$ 検定とカイ 2 乗検定を有意水準 5 \%で行った.

\section{結 果}

肺動脈塞栓症 8 症例について年噛は，48歳から84歳 (平均62.6土9.8葴)で, 男性 2 名, 女性 6 名で標準体 重加らの肥満度が $20 \%$ 以上の肥満が 8 例中 3 例（症例 2. 6.8)あり，そのうち 2 例は $30 \%$ 以上の高度肥满 を示した（表 3 )。手術に関する背景因子を検討した。 疾患甠，8例中 5 例（症例 1，2，3，6，7）方結 腸・直腸癌であった，術式は，直腸癌，S 状結腸癌の骨 盤内手術が 4 例あり，症例の半数を占めた。体位は， 3 例（症例 1.2.7）の直腸切断術の場合でも，載 石位㤝当科で採用しておらず，仰卧位から Simus 位そ して仰臥位と体位変搰している.また，3例(症例 4 。 5．8）の胃癌と 2 例（症例 3．6）の結腸癌は仰卧 位での手術であった。さらに，手術時間も最短 3 時間
表 3 肺動脈血栓症 8 症例の内訳

\begin{tabular}{cccc}
\hline 症例 & 性 & 年秢 & 肥満度 $(\%)$ \\
\hline 1 & 女 & 58 & -22 \\
2 & 女 & 61 & 36.8 \\
3 & 男 & 66 & -8.3 \\
4 & 男 & 56 & -1.2 \\
5 & 女 & 48 & -15.7 \\
6 & 女 & 67 & 22.4 \\
7 & 女 & 84 & 4 \\
8 & 女 & 61 & 30.3 \\
\hline
\end{tabular}

20 分, 最長 9 時間15分, 平均 5 時間 44 分と比較的長〈, それに伴って麻醉時間も長くなり, 出血量も平均 $460 \mathrm{~g}$ と多く，熖環動態への影響も考えた（表 4)。発症時期 は最短は術中から発症し, 最長は術後20日までであっ た。モニター上の異常は血中の酸素濃度低下，主訴と しては肺動脈塞栓症による肺のガス交換の機能低下に よる呼吸苦, 動季を訴え, 術後 2 週間後発症の 2 例(症 例 $1 ． 5 ）$ は, 歩行開始後に深部静脈血栓症による股 
表 4 血栓症症例の病名と手術内容

\begin{tabular}{|c|c|c|c|c|c|c|}
\hline 症例 & 病名 & 衞式 & 体位 & $\begin{array}{c}\text { 手術時間 } \\
(\min )\end{array}$ & $\begin{array}{c}\text { 麻酔時間 } \\
\text { (min) }\end{array}$ & $\begin{array}{c}\text { 出血量 } \\
\text { (g) }\end{array}$ \\
\hline 1 & 直腸癌 & 值腸切断術 & 仰 $\rightarrow \mathrm{S} \rightarrow$ 仰 & 460 & 550 & 570 \\
\hline 2 & 直渴癌 & 㨁腸切断術 & 仰 $\rightarrow \mathrm{S} \rightarrow$ 仰 & 335 & 410 & 730 \\
\hline 3 & $\begin{array}{l}\text { 胃癌 } \\
\text { S状結腸滔 } \\
\text { 肝臓癌 }\end{array}$ & 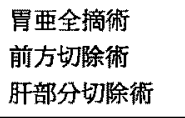 & 仰 & 420 & 505 & 470 \\
\hline 4 & 胃癌 & $\begin{array}{l}\text { 霄要全摘術 } \\
\text { 空腸咅再建 }\end{array}$ & 仰 & 275 & 330 & 210 \\
\hline 5 & 胃路 & $\begin{array}{l}\text { 雷亜全摘術 } \\
\text { 空腸重再建 }\end{array}$ & 仰 & 210 & 300 & 100 \\
\hline 6 & 上行結腸癌 & 右半結腸切除衝 & 仰 & 190 & 270 & 340 \\
\hline 7 & 直腸癌 & 直腸切断術 & 仰 $\rightarrow S \rightarrow$ 仰 & 310 & 380 & 600 \\
\hline 8 & 胃癌 & 冏要全摘術 & 仰 & 555 & 640 & 680 \\
\hline & 仰：伊卧位 & S: Simus位 & $\begin{array}{c}\text { mean } \\
\pm S D\end{array}$ & $\begin{array}{c}344.4 \\
\pm 118.0\end{array}$ & $\begin{array}{c}423.1 \\
\pm 122.0\end{array}$ & $\begin{array}{c}462.5 \\
+212.0\end{array}$ \\
\hline
\end{tabular}

表 5 血栓症発症時期と主訴または異常所見

\begin{tabular}{ccc}
\hline 症例 & 推定術後発症時期 & 主訴または異常所見 \\
\hline 1 & 13 日 & 左股関節痛 \\
2 & 29 時間 & 呼吸困難 \\
3 & 5 時間 & 主訴なし, 動脈血酸素分压低下 \\
4 & 13 時間 & 主訴なし, 動脈血酸索分圧低下 \\
5 & 14 日 & 左股関節痛 \\
6 & 術中 & 動眽血酸素分王低下 \\
7 & 20 日 & 呼吸困難 \\
8 & $11 日$ & 動楼 \\
\hline
\end{tabular}

関節痛を訴えた(表 5)．画像猃断については，今回の 症例は, 病理解剖で診断した 1 例を除き，すべて, 肺 血流シンチと骨盤下肢 MRI 造影または，下肢静脈造 影の陰影欠損像にて, 肺動脈塞栓症とその原因である 下肢静脈血栓症の診断とし可能な場合は肺動脈造影を 行った。 心電図, 心エコーによる検査結果は必ずしも， 右心系負荷の異常や塞栓物を示す心臓内異物峙示さ す, Swan-Ganz カテーテルを留置し測定した 5 例中 1 例（症例 2）のみ肺動脈圧高値を示した。 血栓症素 因とされる生化学的異常として，抗リン脂質抗体を 7 例で検查したが2)，4 例陽性例を認め, 同抗体中のルー プスアンチコアグラントが3例（症例 1.2，4）抗 カルジオリピン $\operatorname{IgG}$ 抗体が 1 例（症例 8 ）陽性であっ た (表 6$)^{334)}$. 治療内容は血栓溶解, 抗凝固潦法とし て肺動脈高血圧症であった 1 例（症例 2）はアルテプ ラーゼ，また，肺動脈造影により塞栓を認めた 1 例(症
例 8 ）にウロキナーゼを使用したが，他は術直後は低 分子へパリンを使用し, 術後数日経過している症例は ヘパリンを使用し，維持療法としてワーファリンを原 則として 6 カ月間服用とした。その内アルテプラーゼ を使用した 1 例と低分子へパリンを使用した 1 例（症 例 3）が治療後ドレーンからの出血のため輸血が必要 となった。また, 下大静脈の造影または造影 CTなど で, 総腸骨静脈合流部に塞栓が連続して存在するなど 肺動脈塞栓症の再発と致死性の可能性が高いと判断し た場合をグリーンフィールド下大静脈フィルターを留 置した。 その内の 1 例は深部静脈血栓症により, 下肢

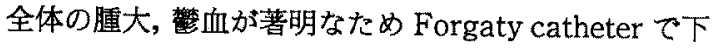
腿静脈の血栓除去を行った症例であった(症例 1). 発 症後の予後は 8 例中 1 例（症例 7) は発症11日後, 肺 動脈塞栓症の診断ができず死亡したが，他の 7 例中癌 死の 2 例（症例 1.8 ）を除き塞恮症の再発なく現在 
表 6 血栓症の診断に重要な画像診断と検查所見

\begin{tabular}{|c|c|c|c|c|c|c|}
\hline 症例 & $\begin{array}{c}\text { 帽血流シンチの } \\
\text { 峏肺野欠賣像 } \\
\end{array}$ & 骨盤下肢MR造影 & $\begin{array}{l}\text { 心電図の } \\
\text { 右心負荷 }\end{array}$ & $\begin{array}{l}\text { 心エコーの } \\
\text { 右心負荷 }\end{array}$ & $\begin{array}{l}S \text { SーGカテの } \\
\text { 肺動脈高血压 }\end{array}$ & 坑リン脂質抗体 \\
\hline 1 & 有 & $\begin{array}{l}\text { 左総腸骨静眽欠損像 } \\
\text { 下大静脈内欠損像 }\end{array}$ & なし & 施行せず & 施行せず & 陽性 \\
\hline 2 & 有 & $\begin{array}{l}\text { 画側総腸骨狰脈久損像 } \\
\text { 下大静脈内欠欠損像 }\end{array}$ & 有 & 有 & 有 & 陽性 \\
\hline 3 & 有 & $\begin{array}{l}\text { 右外腸骨静脈欠損像 } \\
\text { 右大䀶静脈欠欠損像 }\end{array}$ & なL & 描出不良 & なし & 陰性 \\
\hline 4 & 有 & $\begin{array}{l}\text { 左総晹骨静脈欠損像 } \\
\text { 右浅大賢静脈欠賣像 }\end{array}$ & なし & なし & なし & 陽性 \\
\hline 5 & 有 & 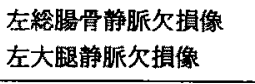 & なし & なし & 施行せず & 陰性 \\
\hline 6 & 有 & $\begin{array}{l}\text { 左総腸骨静脈欠損像 } \\
\text { 下大静眽内欠欠損像 }\end{array}$ & なし & なし & 施行せず & 陰性 \\
\hline 7 & $\begin{array}{c}\text { 剖検で } \\
\text { 左肺動眽血栓 }\end{array}$ & 施行せず & なし & 有 & 施行せず & 検査族行せず \\
\hline 8 & 有 & $\begin{array}{l}\text { 下肢静眽造影施行て } \\
\text { 画下眼静脈欠損橡 }\end{array}$ & なし & なし & なし & 陽性 \\
\hline
\end{tabular}

表 7 血栓症に対する治療内容と予後

\begin{tabular}{|c|c|c|c|c|c|c|c|c|c|}
\hline 症例 & ペリン & 低分子へパリン & ウロキナーゼ & アルテプラーぜ & ワルファリン & 輸血 & フィルター & 手術 & 発症後予後 \\
\hline 1 & 0 & & & & 0 & & 0 & 0 & 26 力月癌死 \\
\hline 2 & & $\mathrm{O}$ & & 0 & 0 & 0 & 0 & & 48 力月生存 \\
\hline 3 & & $\mathrm{O}$ & & & & 0 & & & 39 力月生存 \\
\hline 4 & & 0 & & & 0 & & 0 & & 26 力月生存 \\
\hline 5 & 0 & & & & 0 & & & & 25 力月生存 \\
\hline 6 & 0 & & & & 0 & & & & 22 力月生存 \\
\hline 7 & & & & & & & & & 11日死亡 \\
\hline 8 & & 0 & 0 & & & & & & 12 力月癌死 \\
\hline
\end{tabular}

生存中である(表 7).

肺動脈塞栓症に対する予防策をとっていない時期の 1996年 1月から1999年 1 月のI 期と, 手術時間中弾性 包帯を使用した1999年 2 月から11月のII期と,さらに 術前から術中ならびに術後歩行が十分可能になるま で，弾性ストッキングを使用した1999年12月から2001 年 1 月の川II期とし， 3 期の各時期の症例の背景につい て統計学的に評価した(表 2). それそれれ男女比，年齢， 大腸癌の比, 直腸癌手術の比, 肥満度, 手術時間, 麻 酔時間, 輸血量, 全身林䣲術後肺動脈塞栓症の危険因 子の症例ごとの合計値もすべて有意差は認めなかった

(表 2). しかしながら, 肺動脈塞栓症の予防効果の評 価である肺動脈塞栓症の発生頻度は I 期263例中の 5 例 $1.9 \%$ ，II 期94例中の 3 例中 $3.2 \%$ てっったが， 1999
年12月の弾力性ストッキング使用以降は発生を認めな かったことより, 弾力性ストッキングは肺動脈塞拴症 の予防効果があると考える（表 8 ）。

\section{考 察}

欧米では，術後肺動脈塞栓症は高頻度でありアメリ

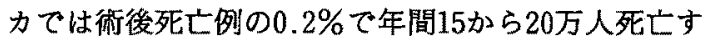
るとされ，また，肺塞栓の $90 \%$ が深部静脈血栓症に起 因するとされている5). 特に, 手術後の樑部静脈血栓症 から肺動脈塞栓症になる例は日本でも増加傾向にある とされている. 術後肺動脈塞栓症の発症原因として は肥満，手術内容だけでは説明できなかった，今回の 症例の検討でも, 術前の肺動脈塞栓症のリスク評価は 単独の因子ではなく，多因子が関係しており，それを スコアーで評価し予防処置を行っている報告がある 
表 8 血栓症に対する予防法と発症率

\begin{tabular}{|c|c|c|c|}
\hline 期間 & 予防対策 & $\begin{array}{c}\text { 異澏大腸癌 } \\
\text { 手術総数 (例) }\end{array}$ & $\begin{array}{c}\text { 肺動脈血栓症 } \\
\text { 発症率(\%) }\end{array}$ \\
\hline I 期：1996/1 1999/1 & なし & 371 & $5(1.35 \%)$ \\
\hline II 期：1999/2〜 1999/11 & 弾性包帶 & 93 & $3(3.23 \%)$ \\
\hline III期 : 1999/12 2001/1 & 弾性ストッキング & 129 & 0 \\
\hline
\end{tabular}

が11，それによると，消化器癌手術は，ほ浬すべて中等 度以上のリスクとなる。したがって，早期診断，治療 が重要である．発症時期は術中から, 術後 3 日以内に 発症し，10日以内に多いとされているが7，自験例でも 半数の 4 例が 2 日以内の発症で 3 週間以降は発生を見 なかったそそれにより，肺動脈塞栓症の発症について は術中から術後 3 週間は注意が必要と考える。実際に は, 術中, 術直後のモニター装着時の突然のパルスオ キシメーターの酸素飽和度の低下や頻脈に注意し, 術 後の患者の意識が清明な時期の術後 3 週間以内は，股 関節など下肢の痛みの主訴に対しても注意が必要であ る. 次に，肺動脈塞栓症を昆った場合の診断法として は，緊急に蘇生術が必要である症例以外は，まず，心 ッドサイドの超音波検查で，大腿静脈の血栓の有無， 心臓内の血栓，右心負荷の所見の確認を傢先する．肺 動眽高圧症を疑う場合, 循環動態の評価，また，血栓 溶解療法にも有利である Swan-Ganz カテーテルを留 置する ${ }^{8)}$.さらに, 可及的早期に, 胸部, 腹部造影 CT, 肺血流シンチ, 骨盤下肢 MRI 造影, 肺動脈造影, 下肢 静脈造影, 可能な範囲で行い画像上の陰影欠損像と, 臨床所見と合わせて下肢静脈塞栓症と肺動脈塞栓症の 晾断を正確に行うき. また, 治療には重症度や, 術後の 経過によって，ヘパリン，低分子ヘパリン，ウロキナ 一ゼ,アルテプラーゼ，を投与する9).しかし，術後早 期は, 抗凝固治療により術後出血を助長し, 出血のた め輸血が必要になる場合がある，また，一般的に出血 傾向が少ないとされている低分子へパリンさえも出血 により投与を途中で断念することもあり，自験例でも この様な症例を 1 例経験し注意が必要と考えた。また， 追加処置として手術や, 肺動脈塞栓症の再発と致死性 の可能性が高いと判断した場合下大静脈フィルターを 留置する". 自験例で手術を行った I例は，深部静脈血

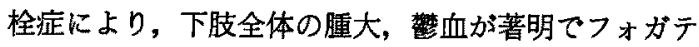
イーカテーテルで下肢静脈の血栓除去を行った症例で あった. 今回，この期間内で外科手術術後に臨床上肺 動脈塞栓症を疑い肺血流シンチを行った症例は報告症 例以外に 1 例あり徒後 2 日目の膵蔵癌であったが，欠
損像は認めなかった。 その症例は，術後心不全により 一過性に呼吸状態が悪化した可能性があり，他疾患の 可能性も考慮しつつ, 疑わしい症例には確定診断のた め画像款断も積極的に行うことが重要と考えた。

肺動脈塞栓症の予防法については, まず, 血液検查 のスクリーニングとして血栓発症萃因とされる生化学 的異常の抗リン脂質抗体を 7 例で検查し 4 例で陽性で あっだ2.しかし，高価で特殊な検査であり術前スクリ ーニングとしては，不適当であると考える．個々の症 例の術前からの肺動脈塞栓症のリスク評価は消化器癌 手術は少なくともすべて中リスク以上のリスクとなる

(表 1$)^{1)}$. そのために欧米のように術中, 術後に予防 的に抗凝固療法を行う方法 ${ }^{10}$ は, まだ, 日本では一般的 でなく，実際，自験例のように術後出血にて輸血が必 要となる症例を経験すると, 抗凝固療法以外の予防療 法が必要と考えた，予防法のII期の上うに弾性包帯は 効果がなかったため，林期のごとく欧米で有効と評価 されている弾性ストッキングを"11, 当院では, 1999年12 月より患者へのインフォームドコンセントを行い了解 の上，全身麻醉の外科症例全例に手術直前より術後十 分に歩行が可能になるまで装着した，現在のところ， 治療を必要とする肺動脈塞栓症の発症はなかった。予 防法における I，II期とIII期の間の深部静脈血栓症の 予防効果の正確な評価は, historical control trial のた め不可能であるが, 各時期の患者背景に統計学上有意 差は認めず(表 2)，予防法を施行していないI期や少 なくとも弾性包带による圧迫は圧迫圧の grading が できないことなどにより有効ではなかったII期より弾 性ストッキングを施行したIII期での肺動脈塞栓症の発 症がなく弾性ストッキングは有効と考えた(表 8). 今 後は，より有効とされている間歇的下肢圧迫法による

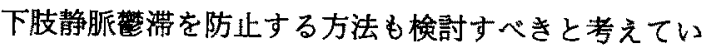
$ろ^{(2) 13)}$.

\section{結語}

胃癌, 大腸癌手術術後肺動脈塞栓症を 8 例経験し, 症例の内容と予防策を検討した. 術前加ら肺動脈塞栓 症の発症を正確に診断するのは困難であるが，すべて 
の胃癌, 大腸癌手術症例が肺動脈塞栓症の発症のリス クが高い症例になると思われ，予防対策が重要である と考えた．抗凝固療法を使用せずに現在のところ弾性 ストッキングにて効果が期待できるが，さらに間歇的 下肢圧迫法も含めた他の予防法の検討も必要と考えた。

\section{文 嗝}

1) Caprini JA, Arcelus JI, Hasty JH, et al : Clinical assessment of venous thrombolic risk in surgical patients. Seminars in Thrombosis and Hemostasis 17 (suppl. 3) : 304-312, 1991

2）三好義範, 题 明人, 小池隆夫：抗りン脂質抗体 症候群. 血栓と媳環 4:48一51，1996

3）高橋芳右：ループス・アンチコアグラント (LA). 内科 $81: 1302-1303,1998$

4) 広烟俊成：抗カルジオリピン抗体. 内科 81 : 1351,1998

5) Borrow M, Goldson $\mathrm{HJ}$ : Prevention of postoperative deep venous thrombosis and pulmo. nary emboli with combined modarlities. The American Surgeon 49:599-605, 1983

6）小池加保児，杉田 真, 佐久間勉：第17回日本䠛 床麻酔学会総会 学術講演肺梗塞. 日臨麻会誌 $18: 545-551,1998$

7）小西成文: 術後深部静脈血拴症に関する研究一と くに予防について一. 日外会誌 $89: 270-281$, 1988
8）藤网 博：私の馀断の strategy. 仲野 越企画・ 構成, 特集肺塞栓症一診潦の strategy Heart View, メジカルビュー社, 東京, 1998, p10-14

9）宮原嘉之，池田 聡：私の治㙩の strategy，仲野 起企画 - 構成, 特集肺塞栓症一診潦の strategy Heart View, メジカルビュ一社, 東京, 1998, p51 $-55$

10) Kakkar VV, Cohen AT, Edmonson RA, et al : Low molecular weight versus standard heparin for prevention of venous thromboembolism after major abdominal surgery. The Lancet 341:259-265, 1993

11）白井理惠, 金田栄子, 小松孝美他：弾力性ストッ キング着用による周手術期の深部静脈血栓症およ び肺梗塞予防の試み. 手術医学 $18: 326-328$, 1997

12) Nicolaides AN, Miles $C$, Hoare $M$, et al : Intermittent sequential pneumatic compression of the legs and thromboembolism-deterrent stocking in the previous of postoperative deep venous thrombosis. Surg $93: 21-25,1982$

13) Scurr JH, Coleridge-Smith PD, Hasty JH: Regimen for improved effectiveness of intermittent pneumatic compression in deep venous thrombosis prophylaxis. Surg 102:816-821, 1982

\title{
A STUDY OF PULMONARY EMBOLISM AFTER DIGESTIVE SURGERY AND GRADED COMPRESSION STOCKING FOR PREVENTION OF POSTOPERATIVE PULMONARY EMBOLISM
}

\author{
Masahide YAMAGUCHI, Tetsuro YAMANE, Susumu NAKASHIMA, \\ Hiroki TANAKA, Yasushi SUGANUMA, Shinji OKANO, \\ Syouzou KITAI, Noboru NAKAGAWA, Mitsuhisa UENO, \\ Yasushi TAKEDA, Masaaki KAMITANI* and Hiroki SUGIHARA* \\ Departments of Surgery and Cardiology*, Matsushita Memorial Hospital
}

Recently pulmonary embolism after surgery for digestive cancer are increasing in Japan. Consecutive eight cases of pulmonary embolism after surgery for gastric and colorectal cancer from January 1996 to January 2001 were studied in terms of prevention and its outcomes. Ages of these patients ranged from 48 to 84 years. The male-to-female ratio was $2: 6$. Three women were obese. The operative procedures included amputation of the rectum in three cases and distal gastorectomy in four cases. Seven patients needed emergency anticoagulant therapy and three patients needed interventional inferior venacaval filter for thrombosis. Only one patient whose diagnosis could not be made during therapy died. A variety of factors causing pulmonary embolism after operation for digestive cancer are thought, and hence it is difficult completely to know the risk of pulmonary embolism preoperatively. Prevention of pulmonary embolism is the most important and effective treatment. The graded compression stocking is useful for prevention of pulmonary embolism after surgery, and has decreased the incidence of postoperative pulmonary embolism after the use of this stocking. The data of patient background between preuse and after use of stocking have no statistical significance. 